\title{
THE STUDY OF TEACHER TALK AND STUDENT TALK IN SPEAKING CLASS
}

\author{
Ida Yulianawati \\ S1 - English Education Department \\ Wiralodra University - Indramayu \\ Ida_yulianawati@unwir.ac.id
}

\begin{abstract}
The paper concerns with investigating classroom interaction especially the classroom language used by teacher and students in teaching learning process in one Junior High School in Indramayu. Teacher's talk signals the classroom language that is used by the teacher in the classroom throughout the class periods. Meanwhile, students' talk signal classroom language that is used by the students. The study employs qualitative interaction analysis method involving fifty nine students and two teachers in two different classrooms. The data are gathered through non-participant observation and video recording. Classroom observations were conducted to gain the data concerning classroom interaction in teaching learning process. The data collecting was separated into twelve categories and analyzed using Flint (Foreign Language Interaction analysis) system adopted from Moscowitz that is widely used to investigate classroom interaction. The findings of this study showed that there are various verbal interactions used in classroom interaction. The data showed that the use of classroom language motivate students to speak and encourage the students to share their idea. But the data also showed that there are many obstacles in using classroom language. So it needs more effort from teachers and students to make classroom language familiar in the classroom.
\end{abstract}

Keywords: speaking, classroom interaction, teacher talk, students talk

\section{INTRODUCTION}

The research will be concerned with the analysis of teacher talk and student talk especially conversational analysis in a Junior High School. It is believed that the students can acquire the material taught in their classes better when it is part of interaction rather than simply exposed to spoken or written text (Gass, et al cited in de Bot, et al. 2005:176, Long in Ellis,1997: 47, Ellis, 1996:28, Johnson, 2004:85). Conversational interaction involving second language (L2) learners and their interlocutors has been central to second language acquisition (SLA) since the early 1980s. A good deal of this work has focused on the ways in which interaction can be influenced by factors of gender, ethnicity, and the role of social relationship of learners and their interlocutors, and by the nature of topics, tasks, and activities in which they engage. Considerable attention has also been directed toward the role of interaction with respect to the conditions considered theoretically important for SLA, such as the learners' comprehension of input, 
access to feedback, and production of modified output (Gas, 1997 cited in de-Bot, et al. 2005:177).

One of difficulties that are faced by the students is lack of opportunity to practice English in the class. As the researcher experience that some English teachers only use English when they explain the material to the students and they use bahasa Indonesia to interact with students. In a class where English is only used as a learning material, the students will feel that English is not part of their life. When the teacher and students use English not only as a material but also as a medium to learn English, then it may help the students to speak better. Because activities involving real communication, carrying out meaningful tasks, and using language that is meaningful to the learner (Nunan: 1999:246).

The previous studies on classroom research aimed to figure out the features of classroom interaction in story-based lesson through detailed analyses of classroom discourse in a teacher fronted classroom setting $(\mathrm{Li}$ and Seedhouse; 2010). Another classroom research was conducted by Ridho (2010) who investigated the function of discourse marker in an interpersonal-interactive feature in a science lecture.

\section{LITERATURE REVIEW Classroom Language}

Using classroom language in teaching speaking means to speak and to use English in the classroom as much as possible. For example when organizing teaching activities or chatting to the students socially. In other words, it means establishing English as the main language of communication between the students and teacher. The students must know that it does not really matter if they make mistakes when they are talking, or they fail to understand every word that the teacher says. The students must recognize that if they want to use their English at the end of their study, they must practice using it during the English lesson. Classroom language contains simple meaningful expressions that help the students to get involved in the activities in the classroom easily.

The primary function of language is to communicate information. In the classroom, information gaps occur repeatedly, that is, the teacher has new information which the students require in order to continue participating in the lesson, or the students have answers which the teacher needs in order to know whether to proceed to the next stage of the lesson. These Much of the language that is used by the students in the name of practice may have little direct application outside the classroom, but many classroom management phrases can be transferred to "normal" social situations, e.g. Could you open the window: I'm sorry I didn't catch that. By using these phrases the teacher is demonstrating their contextualized use and indirectly accustoming the students to the form-function relationship that are part of English (Hughes 1990: 7).

Classroom situation and procedures are generally quite concrete, which means that most classroom phrases have very clear situational link. For example, given a specific context (repetition after tape) which familiar to the students, the students should be able to choose from 'All together', 'The whole class', 'Everybody', 'The whole class', 'Not just this row, 'Boys as well', 'In chorus', or 'Why don't you join in?' and the students should be able to react appropriately. In 
fact, by varying the phrases used in particular situation, the teacher is giving the students a number of free learning bonuses. Kramsch cited in Thornburry (2005:123) offers some ground rules whereby more say can be devolved to the students, through for example, allowing them topic control and giving them more responsibility for the turn taking in the classroom talk. Here are some of her 'rules' for teacher:

1. Use the target language not only to deal with the subject matter but also to regulate the interaction in the classroom.

2. Keep the number of display questions (i.e. teacher questions are aimed at getting learners to display their knowledge, such as "What's the past tense of go?) to a minimum.

3. Build the topic at hand together with the students; assume that whatever they say contributes to the topic..

4. Tolerate silences; refrain from filling the gaps between turns. This will put pressure on the students to initiate turns.

5. Encourage students to sustain their speech beyond one or two sentences and to take longer turns; do not use a student's short utterance as a springboard for your own lengthy turn.

6. Extend your exchanges with individual students to include clarification of the speaker's intentions and a negotiation of meanings; do not cut off too soon an exchange to pass to another student.

7. Pay attention to the message of students' utterance rather than to the form in which they are cast. Keep your comment for later.

8. Make extensive use of natural feedback ('hmm'/ 'interesting'/ 'I thought so too') rather than evaluating and judging every student utterance following its delivery ('fine'/ 'good'). Do not over praise.

9. Have students' explicit credit by quoting them ('just as x said'); do not take credit for what students contributed by giving the impression that you had thought about it before.

\section{Speaking}

For most people, the ability to speak a language is synonymous with knowing that language since speech is the main basic means of human communication (Hughest; 2002, Nunan 1999, O'Malley and Pierce 1996, etc). Nevertheless, "speaking in a second or foreign language has been often viewed as the most demanding of the four skills" (Bailey and Savage cited in Lazaraton (2001:103).

In our curriculum, teaching learning activities require that English teacher have a good mastery of the four skills. Without a good mastery of the language skills, English teachers will not be able to help their students acquire the language skills. In the classroom, English teacher should be able to manage the class by involving the students in the activities. There are some different approaches that have been used over years to teach languages. Although there are many different methods in language teaching, three methods have dominated language teaching in the past sixty years. They are:

There are many ways to make the students interested to get involve in speaking activities. The teacher should be creative to find the right ways to his/her 
students. These are the types of classroom speaking performance according to Brown (1994:266):

- Imitative

A very limited portion of classroom speaking time may legitimately be spent in the human "tape recorder" speech, where learners are, for example practicing an intonation contour, trying to pinpoint a certain vowel sound etc.

- Drilling

Drills offer students an opportunity to listen and to orally repeat certain strings of language that may pose some linguistic difficulty-either phonological or grammatical.

- Intensive

Intensive speaking can be self-initiated or it can even form part of some pair work activity, where learners are "going over" certain forms of language.

- Responsive

A good deal of students' speech in the classroom is responsive: short replies to the teacher or student initiated questions or comments.

- Transactional (dialogue)

Transactional language, carried out for the purpose of conveying or exchanging specific information, is an extended form of responsive language. Conversations, for example, may have more of a negotiative nature to them then merely responsive speech.

- Interpersonal (dialogue)

The other form of conversational mentioned in the previous chapter was interpersonal dialogue, carried out more for the purpose of maintaining social relationships than for the transmission of facts and information.

- Extensive

Finally, students at intermediate to advanced levels are called on to give extended monologues in the form of oral reports, summaries, or perhaps short speeches.

\section{Teacher Talk and Student Talk}

The language that the teacher uses at the beginning of the lesson and the topics of conversation will depend on what of the week it is, the time of the day and whether or not anything particularly interesting recently. The teacher should remember that her/his aim in class is to show to her/his students that English can be used for communication purposes and that it is not just another textbook subject to be studied and not used.

1. How the teachers start using English?

Even with a class of beginners starting their first English lesson, it is possible to teach entirely in English. On the other hand a class in its second or third year of English which is used to receive all explanations and instructions in Bahasa Indonesia is likely to resent the intrusion of English into the English class and make a fuss. Something to be remember that the students will only accept this argument if it can be shown to work. For example the instruction "Would you close the books, please?" should at this stage be accompanied by a clear demonstration. The teacher should pick up a book from his/her desk and 
close it as he/she gives the instruction. If only a few students understand and obey, they should be praised "Good, you have closed your books."

2. Stage the language

It will be easier for the beginner students if the teacher introduces classroom English slowly. With students who have learnt some English before, it is a good idea to try at first to keep mainly to the vocabulary and structures that they have already covered in their previous work. When they have got used to hear and understand these, and perhaps using some of them for themselves, the teacher can introduce other useful phrases.

3. Praise before correction

Neither teacher nor students should not to worry too much about small mistakes. The important thing is that students should understand and be understood. If a student ask the question "You want collect our book?" he should be corrected but first and more important, he should be praised "Good. Well done. Yes, I want to collect your books." The teacher asks questions again so everyone can hear it. Listen, "Do you want to collect our books?" In this way the form of the question has been corrected but the student has been given full credit for making himself understood.

\section{RESEARCH METHODOLOGY}

In this study, the researcher relied on qualitative research method since she wanted to go deeply to generate data become rich and embedded in context. Furthermore, because the researcher is interested to do the research about classroom interaction in the real classrooms, she chooses interaction analysis as the method of research. Interaction analysis is one of methods for analyzing classroom interaction involves the discursive analysis of classroom talk. Long as cited in Celce-Murcia (2001:489) defined classroom research as "research on second language teaching and learning, all or part of whose data are derived from the observation or measurement of the classroom performance of teacher and students."

The research was undertaken in one Junior High School in Indramayu. The participants of this study were fifty nine students and two teachers in two different classrooms.

\section{Data Collection}

As outlined above, the data are gathered through two ways namely nonparticipant observation and video-recording. The researcher observes and video taping the teaching learning process the classroom and then transcribe it using Foreign Language Interaction analysis (FLint) system as guidance.

\section{Data Analysis Method}

The data of the research are analyzed through qualitative data analysis. The data analysis was immediately conducted after the data from observation transcription are available. There are two approaches in analyzing the data from observation; they are unstructured and structured method. In this research, the researcher uses structured approach. In structured approach, the researcher's analysis is guided by Foreign Language interaction analysis (FLint) system. 
The data from observation were transcribed and analyzed to figure out the kind of classroom language used in teaching speaking and its implication in classroom interaction. The analysis was done by describing the teaching learning process and interaction between students and students and between students and the teacher, comment from observation and the transcription from video tape. The classroom language that used in the classroom was separated into 12 category according to Flint system (see the appendix to get complete information about Flint system).

The coding of the data was made to protect the confidentiality of the participants. It was also meant to make the data analysis easier. The coding was as follows.

\section{Coding}

\begin{tabular}{|l|l|}
\hline \multicolumn{1}{|c|}{ CODING } & \multicolumn{1}{c|}{ MEANING } \\
\hline T1, T2 & Teachers as the participants of the research \\
\hline M1, M2 etc. & Identified male student \\
\hline F1, F2 etc. & Identified female student \\
\hline M & Unidentified male student \\
\hline F & Unidentified female student \\
\hline MV & Female voice from videotape \\
\hline FM & Female voice from videotape \\
\hline LL & Unidentified subgroup of class \\
\hline$\underline{\text { LL }}$ & Unidentified subgroup of class speaking in chorus \\
\hline LLL & Whole class \\
\hline$\underline{\text { LLL }}$ & Whole class speaking in chorus \\
\hline
\end{tabular}

\section{FINDINGS AND DISCUSSION}

This section aims to report and describe the data collected through nonparticipant observation. The analysis of classroom English is using Foreign Language interaction analysis (FLint) system adapted by Moscowitz as cited in Allright and Bailey (1991:204-205). The data were separated into two categories, they are teacher talk and students talk. The analysis is as follow:

\section{TEACHER TALK}

The data below were used to explain the language that is used by the teacher. They are separated into four categories. They are: 
1. DEALS WITH FEELINGS: In a non-threatening way, accepting, discussing, referring to, or communicating understanding of past, present, or future feelings of students.

Transcription from T1 class:

T1 : Good morning, students.

LLL : Good morning, mam.

T1 : How are you today?

LLL : I'm fine. Thank you, and you?

T1 : I'm fine too, thank you.

In term of dealing with feelings of students, the data indicated that both teachers seemed to be aware that they need to make the students familiar with the English. It is relevant to an argument proposed by Kramsch cited in Thornburry (2005:123). She says that "the use the target language not only to deal with the subject matter but also to regulate the interaction in the classroom." From the transcription above, we know that the teacher and students did not have any difficulties to give the questions and to give responses. It was possible because from the informal interview with the teacher and some of the students, both of teacher and students always do the greeting and ask about each other condition at the beginning of the class.

2. PRAISES OR ENCOURAGES: Praising, complementing, telling students why what they have said or done is valued. Encouraging students to continue, trying to give them confidence. Confirming answers are correct.

Transcription from $\mathrm{T} 1$ class:

T1 : Annisa, what did you do yesterday?

F3 : ..... [silent]

T1 : What did you do yesterday? Please tell one activity you did yesterday.

F3 : I uh.... Xx [say something unclear]

T1 : Pardon?

One thing you did yesterday.

F3 : Mmm .... Xx

Do you remember one thing you did yesterday?

T1 : Please say it in English. One thing you did yesterday

F3 : I ... went to library

T1 : Good. You went to the library.

From the transcription above, we know that the teacher tried hard to make one of her students speak English. Even though at the beginning of conversation, the student did not answer it clearly and even spoke in Bahasa Indonesia, the teacher finally succeeded to make her say something in English. After the student gave the answer, the teacher praised her by saying "good". Nunan cited in Brown (1994:255) says that "one learner's performance is always colored by that person (interlocutor) he or she is talking with." It means that a conversation will run smoothly if there is understanding between the speaker and the listener. The transcription also shows us that the teacher did not mind to wait 
when the student tried to find English words to answer her question. It is relevant to an argument proposed by Kramsch as cited in Thornburry (2005:123). She says that "one of the rules for teacher is to tolerate silence."

3. USES IDEAS OF STUDENTS: Clarifying, using, interpreting, summarizing the ideas of students. The ideas must be rephrased by the teacher but still recognized as being student contribution.

Transcription from T1 class:

$\begin{array}{ll}\text { T } & \text { : Ok. Tantyo, what did you do yesterday? } \\ \text { M26 } & \text { : I didn't ... I didn't go anywhere. } \\ \text { T } & \text { : You didn't go anywhere? Why? } \\ & \text { You didn't go to your school? } \\ \text { M26 } & \text { : Oh yeah bu. Yes, I went to school. }\end{array}$

The transcription above shows us how the teacher made an effort to get the student to speak. She gave the idea to the students and the student used the idea from the teacher to explain his activity. Kramsch cited in Thornburry (2005:123) offer her idea to: "Build the topic at hand together with the students; assume that whatever they say contributes to the topic." It means that the teacher needs to listen to the student's idea because it will arouse the students' interest to get involve in the discussion. The transcription above also shows us that the teacher used inference question by asking "What did you do yesterday?" Inference question is one kind of questions that is effective in the classroom. (Kinsella and Bloom as cited in Brown 1994: 166). When the students answered the question, the teacher asked him another question based on student's idea.

Transcription from T2 class:

T2 : Ok, students. I think today I have some questions for you. Uh...

When you are child. When you are in elementary school, before you

$\underline{\mathrm{LL}} \quad$ : Yes getting a bed, have you ever heard about folktale from your mother?

T2 : Such as kancil and buaya, or such as ...

F : Cinderella.

T2 : Ya, Cinderella. Have you ever heard about that story?

LLL : Yes.

From the conversation above, we know that the teacher used the idea from the students by saying "Ya, Cinderella. Have you ever heard about that story?". The teacher tried to connect the material with the students' childhood memory. Not many verbal interactions can be reported from this category because the students only answer the teacher's question with short answer.

1. ASKS QUESTIONS: Asking questions to which an answer is anticipated. Rhetorical questions are not included in this category.

Transcription from $\mathrm{T} 1$ class:

T1 : What about you, Robby. What did you do yesterday? Did you eat breakfast?

M21 : Yes, I ate breakfast.

T1 : Oh, you ate breakfast. 
The conversation above shows us that the teacher gave the idea to the students and the answer is already anticipated by the teacher. When the teacher asked "Did you eat breakfast?", the student did not have any difficulties to give the answer. The students gave their responded enthusiastically. The conversations run smoothly because both teachers and students understand each other. Therefore, as Nunan cited in Brown (1994:255) says that "one learner's performance is always colored by that person (interlocutor) he or she is talking with." It means that to make a conversation, both speakers need to know about the topic and turn taking.

3. GIVES INFORMATION: Giving information, facts, own opinion or ideas, lecturing, or asking rhetorical questions.

Transcription from T1 class:

Conversation 1

T1 : Students, today we will talking about the activity you did yesterday.

Jadi, kegiatan speaking hari ini akan membahas tentang kegiatan yang sudah kamu lakukan. [the teacher use bahasa Indonesia to make sure that students understand the material]

The conversation above was talking about how the teacher gave information about what the class would learn about. At first, the teacher spoke English to give information about the material that would be taught that day, but then she repeated the information in Bahasa Indonesia. The writer assumed that the teacher wanted to make sure that her students understood about the information.

Transcription from T2 class:

T2: Cinderella, I think this story is very famous for you. And today we are going to learn about folktale. Please answer my question. Mention some folktale that ever heard.

$\mathrm{F}$ : Cinderella

$\mathrm{M}$ : Si kancil

$\mathrm{M}$ : Beauty and the beast.

$\mathrm{M}$ : Pinokio

From the conversation above, the teacher informed that the students will learn about "folktale". She assumed that the students were already know about the story of "Cinderella". She asked the students to mentions about some folktale that the students knew and students answered eagerly.

5a. CORRECT WITHOUT REJECTION: telling students who have made a mistake the correct response without using words or intonation which communicate criticism.

Transcription from T1 class:

T1 : Syarif, what did you do yesterday?

M24 : I play badminton. 
T1 : Oh, you played badminton.

M24 : I played badminton.

The conversation above shows how the teacher responded when the student made a grammatical mistake. She did not tell the student that his sentence was in the wrong order but she simply repeated the student's sentence in the right order. As the result, the student repeated the right sentence. A whole conversation was in English. The teacher seemed to be aware that her correction on students' speaking should give them the message that mistakes are not bad and the ability of the students to self-correct indicated readiness to regularly use the English form correctly. The teacher seemed to be aware that the students will not want to practice if they are afraid of making mistakes which result in interruption and correction. It is relevant to Gass in de-Bot (2005: 180) who says that feedback becomes the impetus for learners to recognize the inadequacy of their own rule system. This is in line with Han (2003:30) who says that quality of input is a contributing factor to fossilization. It means that in this case, the teacher's feedback avoid fossilization.

6. GIVES DIRECTION: Giving directions, requests or making commands which students are expected to follow.

Transcription from T1 class:

Conversation 1

T1 : Ok. Students!

Now ask to your friend beside you [mmm... looking at certain student] Where about Annisa? Oh you there. Annisa and you [pointing one of students]

Chandra! You turn up to Annisa, ok?

Denny! Denny, please move here!

Deny move here! [the teacher points on desk in front row. Denny brings his chair and walks quietly to the front row]

Now, special for this group [pointing at the students who sit in the middle] there are three students in a group.

From the conversation above, the teacher asked certain students to work together. The conversation show us that the teacher used discourse marker "Ok" and "now" to mark the beginning of segment of talk. The teacher used English in managing the class. By managing the class deliberately and flexibly, the teacher is taking an important step to remove the barriers between controlled and often meaningless practice and more genuine interactional language use.

Transcription from $\mathrm{T} 2$ class:

Conversation 1

T2 : Now, please make a group of four

[Students are busy and the class is noisy]

T2 : Ok. Sekarang, ibu akan memberikan satu buah kertas kosong dan 
satu buah amplop yang di dalamnya ada cerita. Hanya, di dalamnya ceritanya masih berbentuk acak. Artinya nanti setiap paragraph harus kamu susun sehingga membuat satu cerita yang padu. Nanti ditempel di kertas yang kosong ini.

[Students are busy and they talk to each other loudly so the verbal interaction can not be recorded. They spend about 15 minutes to do the group work. The teacher walks around the class to check the students' work and help those who need help. Some students read the story while the others talk about the task with their friends in bahasa Indonesia].

In conversation above, the teacher asked the students to make groups of four, and the students followed it directly. This is relevant with Bailey and Savage cited in Lazaraton (2001:103) who say that "Pairwork and groupwork are typical organizational features of interactional features of interaction-based lesson in Communicative Language learning. The next command was given in Bahasa Indonesia. The students followed the command. Not much verbal interaction could be reported because the teacher is the only one who talks.

7. CRITICIZES STUDENTS BEHAVIOR: Rejecting the behavior of students; trying to change from the non-acceptable behavior, communicating anger, displeasure, annoyance, dissatisfaction with what students are doing.

T1 : Chandra, Annisa and Titin!

[Three students are standing in front of the class. They will perform conversation but the class is crowded, students did not pay attention]

\section{Attention!}

Students! [students stop talking and pay attention]

Please be quite!

And the students in front of the class please be louder!

LLL : [The class is quiet]

The transcription above shows us that the teacher tried to make the class quiet by saying "Attention!" and "Please be quite". It was related to the students' behavior in the classroom. The teacher wanted to make sure that the students paid attention when other students performed the conversation in front of the class. There was no verbal interaction between the teacher and the students because the teacher was the only one who gave command and the students only did what the teacher said. The conversation is also related with number 10 about silence.

\section{STUDENTS TALK}

8. STUDENT RESPONSE, SPECIFIC: Responding to the teacher within a specific and limited range of available or previously shaped answers. Reading aloud.

Transcription from T1 class: 
T1 : How about you ...x? What did you drink this morning?

MV : I drink milk

T1 : Oh, milk. A glass of milk or a cup of milk?

MV : A glass of milk

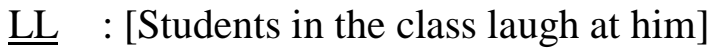

From the conversation above we know that the teacher asks about something that the student did this morning. The student only gave limited answer because the teacher asked him about something he drank this morning. The student answered the question easily. Unfortunately, the teacher did not correct the student's mistake in suing past tense. It seems that the student did not aware that he shoulduse 'drank' instead of 'drink'. If this happen simultaneously, it will be possible that the student will have 'fossilization', because fossilization occurs because of absent of feedback (Han, 2003: 28). The conversation was also related with number 9 about students' response and number 12 about laughing. It is relevant to Brown (1994:266) who propose that "A good deal of students' speech in the classroom is responsive: short replies to the teacher or student initiated questions or comments. These replies are usually sufficient and do not extend into dialogues."

9. CONFUSION, WORK-ORIENTED: More than one person at a time talking, so the interaction cannot be recorded. Students calling out excitedly, eager to participate or respond, concerned with task at hand.

Transcription from $\mathrm{T} 1$ class:

T1 : Now, the time signal is up to you, (She points the dots).

This time signal is up to you. "when" you will ask him or "when" you will ask her. Ok!

Last night, last month, last week and one question "What will she or what will he do?." You can ask him or ask her tomorrow, next week, next month, next day, two days after today.

So, prepare two questions and ask your friend and your friend will ask two questions too for you. So you must answer his or her questions. I will give you ten minutes to prepare it. Ten minutes to prepare questions to your friend and prepare your answer and your friend will ask you two questions for you, too.

\section{Ready?}

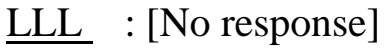

$\mathrm{T} 1 \quad$ : Ten minutes and you will perform it in front of the class. You ask your friend and your friend will ask you.

Ok? Prepare it!

$\underline{\mathrm{LL}}$ : Maju bu?

$\mathrm{T} 1$ : Yes, in front of the class.

[The class is crowded. Students speak loudly to their friends. Most of them use Bahasa Indonesia to speak to their friends. Some students are approaching their friends and start talking and laughing. The teacher walks around to check the students' work. 
After about 15 minutes, the teacher standing in front of the class and says that there is no more practice].

When the teacher asked the students to tell the story to their friends, there was so much noise in the class. Some students looked eager to tell the story, while others look confused and did not know what they have to do.

To sum up the transcription above gives clear description about what is going on in natural classroom The twelve categories shows the ability of the teacher to maintain English as primary language in the classroom although both teachers and students still use bahasa Indonesia to keep the verbal interaction run smoothly.

\section{CONCLUSION}

The present study serves as an attempt to investigate classroom interaction especially verbal interaction used in English class. The major conclusion of the study is that the participants who involved in this research basically use classroom language in their classes. The twelve categories of Foreign Language interaction analysis (FLint) system have become proof of the use of classroom language. The result of the study also indicates that the teachers and students have spent a part of their time spoke in bahasa Indonesia to keep the verbal interaction running in the class.

Regarding the influence of classroom language in speaking class, the transcription clearly showed that the more the students feel familiar with the classroom language, the easier they interact with teacher and other students. But when the students are not familiar with classroom language, they are confused and do not know what to do when the teacher asked them to do something. So, it needs a lot of effort both from the teachers and the students to make classroom language become their daily routine.

\section{Suggestion}

This research only investigated classroom language in a simple way and only took two classes in two sessions. Therefore, a further research can be conducted in different setting with more participants. Furthermore, as this study was only used Foreign Language interaction analysis (FLint) system, further study can also use other way to investigate classroom interaction.

\section{REFERENCES}

Allwright, Dick and Kathleen M. Bailey. 1991. Focus on the Language Classroom: An Introduction to Classroom Research for Language Teacher. Cambridge: Cambridge University Press.

Brown, Douglas H. 1994. An Interactive Approach to Language Pedagogy. New Jersey: Prentice Hall Regents. 
Chaudron, Craig. 1988. Second Language Classrooms: Research on Teaching and Learning. Cambridge: Cambridge University Press.

Cox, Carole. 1998. Teaching Language Arts. California: Allyn and Bacon.

de-Bot, Kees et al. 2005. Second Language Acquisition: An Advanced Resource Book. Oxon: Routledge.

Ellis, Rod. 1996. The Study of Second Language Acquisition. Oxford: Oxford University Press.

Elis, Rod. 1997. Second Language Acquisition. Oxford: Oxford University Press.

Freeman, Diane Larsen. 1985. Techniques and Principles in Language Teaching. Oxford: Oxford University Press.

Gebhard, Jerry. G. 2000. Teaching English as a Foreign or Second Language: A Teacher Self-Development and Methodology Guide. Michigan: The University of Michigan Press.

Han, ZhaoHong. 2003. Fossilization in Adult Second Languge Acquisition. Clevedon: Cromwell Pres

Harmer, Jeremy. 2007. How to Teach English. London: Longman.

Hughes, Glyn S. 1990. A Handbook of Classroom English. Oxford: Oxford University Press.

Hughest, Rebecca. 2002. Teaching and Researching Speaking. London: Longman.

Johnson, Marysia. 2004. A Philosophy of Second Language Acquisition.New York: Yale University.

Littlewood, William. 1988. Communicative Language Teaching: An Introduction. Cambridge: Cambridge University Press.

Nunan, David. 1992. Research Methods in Language Teaching. Cambridge: Cambridge University Press.

Nunan, David. 1999. Second Language Teaching and Learning. Boston: Heinle \& Heinle.

Paul, David. 2003. Teaching English to Children in Asia. Hong Kong: Pearson Education Asia Limited.

Richard, Jack C. and Theodore S. Rodgers. 1982. Approaches and Methods in Language Teaching. Cambridge: Cambridge University Press.

Thornbury, Scott. 2005. How to Teach Speaking. London: Longman

Ur, Penny. 1996. A Course in Language Teaching: Practice and Theory. Cambridge: Cambridge University Press. 
WEJ, Vol 2 No 2 September 2018

Willis. Jane. 1986. Teaching English through English. London: Longman.

Wragg. E. C. 1994. An Introduction to Classrroom Observation. London: Routledge. 